\title{
Craniometry in Cerdocyon thous (Carnivora, Canidae)
}

\author{
Craneometría en Cerdocyon thous (Carnivora, Canidae)
}

\author{
Antonio Maximiano Neto ${ }^{1}$; Wilson Viotto de Souza²; Lilja Fromme ${ }^{3}$; Mariana Gomfran Domingues ${ }^{2}$; \\ Lorena Pereira Guimarães²; Thaís Aparecida Silva² \& André Luiz Quagliatto Santos ${ }^{2}$
}

NETO, A. M.; VIOTTO DE SOUZA, W.; FROMME, L.; DOMINGUES, M. G.; GUIMARÃES, L. P.; SILVA, T. A. \& SANTOS, A. L. Q. Craniometry in Cerdocyon thous (Carnivora, Canidae). Int. J. Morphol., 38(3):640-644, 2020.

SUMMARY: The objective of this study was to obtain data on craniometric parameters in the crab-eating fox (Cerdocyon thous) and to define the general skull type of this species, analysing whether the craniometric classification of domestic dogs can be applied. Eleven skulls of $C$. thous were included in the analysis, irrespective of age and sex. The location of nine craniometric points established for craniometry in domestic dogs was determined and based on the distances between these points, 17 craniometric parameters were measured. Those parameters were used to calculate the following six craniometric indices: $53.17 \pm 2.54 \mathrm{~mm} \mathrm{skull} \mathrm{index,} 2.33 \pm 0.08 \mathrm{~mm}$ craniofacial index, $59.17 \pm 3.57 \mathrm{~mm}$ neurocranial index, $125.58 \pm 6.63 \mathrm{~mm}$ facial index, $37.52 \pm 2.65 \mathrm{~mm}$ basal index and the index of the foramen magnum $54.47 \pm 3.48 \mathrm{~mm}$. According to the analysed indices, the skull shape in $C$. thous can be classified as mesaticephalic.

KEY WORDS: Wild canid; Skull; Morphometry.

\section{INTRODUCTION}

Cerdocyon thous (Linnaeus, 1766), the crab-eating fox, is a member of the family Canidae and occurs in a wide range of the Brazilian territory, from dense forests to open grasslands, with exception of the federal states Acre and Amazonas (Berta, 1982; Machado \& \& Hingst-Zaher, 2009; Lucherini, 2015). Adult animals weigh from five to eight $\mathrm{kg}$ and measure approximately $65 \mathrm{~cm}$ from head to tail (Berta; Emmons \& Feer, 1997). C. thous is a nocturnal and crepuscular species, omnivorous, a generalist and opportunist (Berta; Langguth, 1975).

Nevertheless, the species is affected by habitat fragmentation and road mortality and threatened by hunting from farmers and the proximity to domestic dogs and their potentially contagious diseases (Cheida et al., 2011; Lucherini).

Moura et al. (2007) point out that the interaction of wild animals with their natural habitat or their environment in captive conditions can be better understood, based on morphological studies. Basic knowledge of morphological characteristics in wild species might be crucial for conservation strategies. Therefore, the anatomy of wild animals, including the skull, needs to be studied.
The skull is a part of the axial skeleton, forming the head skeleton and enclosing the brain, sensory organs and digestive and respiratory structures. It consists of two parts: the neurocranium and the viscerocranium. The neurocranium surrounds and protects the brain and is composed of flat and irregular bones. The viscerocranium comprises the facial bones, consisting of irregular bones and the mandibula (Nickel et al., 1986).

Machado (2006) states that the shape of the skull is one of the most important criterions for establishing racial patterns and evolution models for species. Some works on comparative osteometry in mammalian species with focus on phylogeny and evolution have been published by Christiansen (1999), Lyras \& Van Der Geer (2003), Ferguson \& Larivière (2004) and Goswami (2006).

Domestic cats previously have been the object of analyses in order to establish craniometric patterns (Sarma et al., 2002) and domestic dogs have been studied even more profoundly (Machado; Evans \& De Lahunta, 2013; Shimming \& Pinto e Silva, 2013). The skull type in domestic dogs is classified employing the skull index, which allows to distinguish three morphological categories:

\footnotetext{
${ }^{1}$ Federal Institute of Triângulo Mineiro (IFTM), Campina Verde, MG, Brazil.

${ }^{2}$ Laboratory of Wild Animals Teaching and Research, Federal University of Uberlândia (UFU), Uberlândia, MG, Brazil.

${ }^{3}$ University of Veterinary Medicine Hannover, Bünteweg, Hannover, Germany.
} 


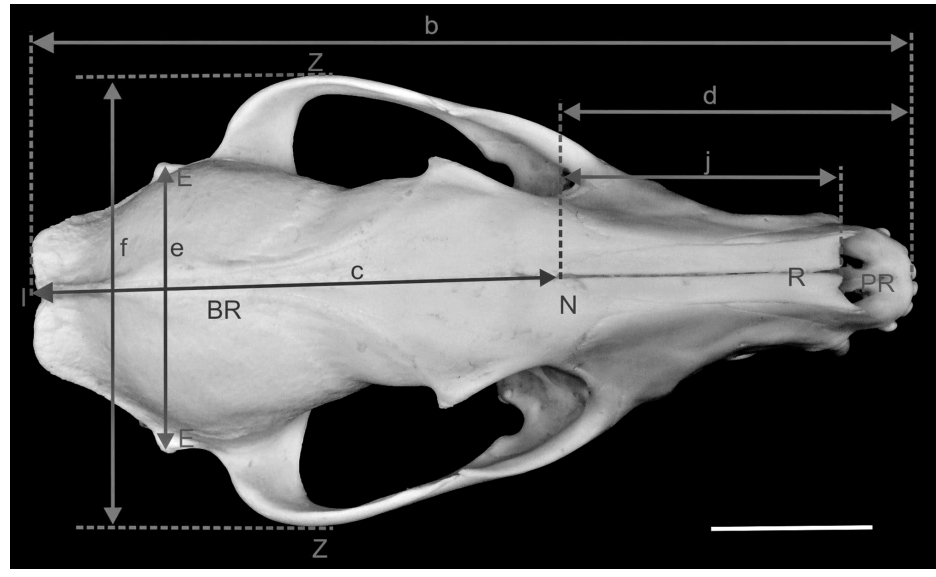

Fig. 1. Photograph of the skull of C. thous, dorsal view. BR (Bregma), E (Eurion), I (Inion), N (Nasion), PR (Prosthion), R (Rhinion), Z (Zygion), b (Length of the skull), $c$ (Length of the neurocranium), d (Length of the viscerocranium), e (Width of the neurocranium), $f$ (Zygomatic width) and $j$

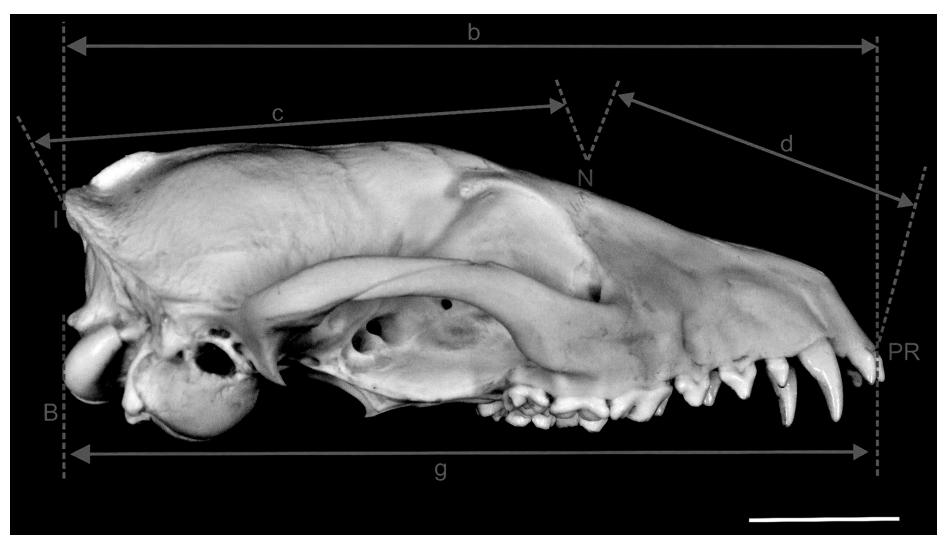

Fig. 2. Photograph of the skull of $C$. thous, lateral view. B (Basion), I (Inion), N (Nasion), PR (Prosthion), b (Length of the skull), c (Length of the neurocranium), $d$ (Length of the viscerocranium) and $g$ (Length of the base of the skull). Scale: $3 \mathrm{~cm}$.

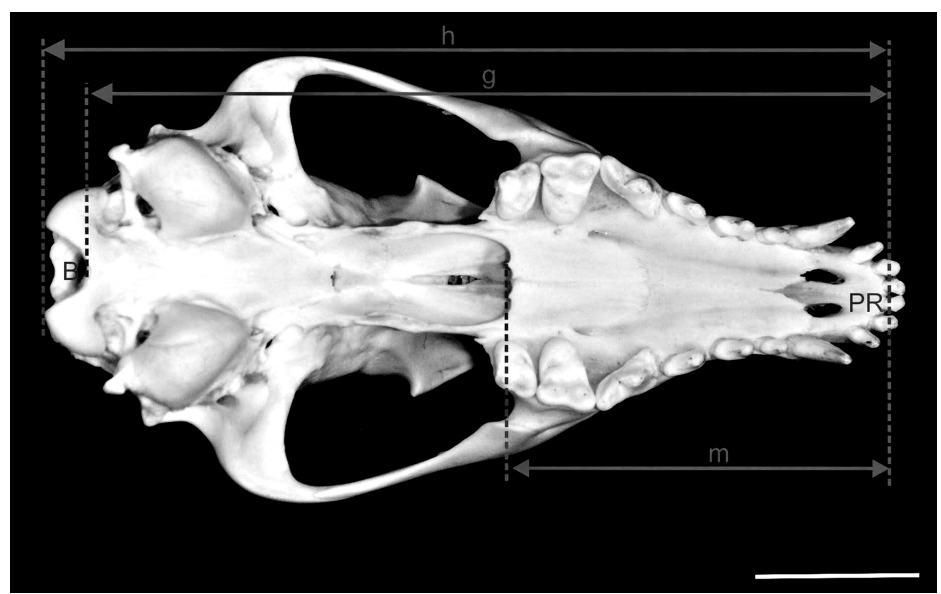

Fig. 3. Photograph of the skull of C. thous, ventral view. B (Basion), PR (Prosthion), g (Length of the base of the skull), h (Condylobasal length) and $\mathrm{m}$ (Palatal length). Scale $3 \mathrm{~cm}$. brachycephalic, mesaticephalic and dolichocephalic skulls (Evans \& De Lahunta).

Literature on skull morphology in wild animals is rare. Christiansen \& Adolfssen (2006) studied the skulls of 56 wild carnivores, including felids, canids and ursids. Nevertheless, the authors focussed on aspects related to the mastigatory force and did not concentrate on craniometric patterns. Furthermore, Santos et al. (2017) realized a study with seven maned wolves (Chrysocyon brachyurus), verifying whether the craniometric data collected allows a classification of the skull type after Getty (1986). According to Hofmann-Appollo (2009), various wild canid species present an intermediate skull type, being classified as mesaticephalic and therefore resembling the domestic dogs.

The objective of this study was to realize craniometric measurements in C. thous, patronize the craniometric values for this species and compare these characteristics to the craniometric patterns in domestic dogs in order to conclude whether the classification of skull types (dolicho-, mesati- and brachycephalic) is appropriate for $C$. thous as well.

\section{MATERIAL AND METHOD}

A total of 11 skulls of $C$. thous were used in this study, irrespective of age and sex. The samples were collected from road-kill specimens with the approval of the Biodiversity Information and Authorization System (SISBIO, permit $n^{\circ} 49266-1$ ) and belong to the anatomical collection of the Wild Animal Research Laboratory of the Federal University of Uberlândia. Craniometric points, parameters and indices that were applied in this study, were based on works on craniometry in domestic dogs (Simoens et al., 1994; Onar \& Günes , 2003; Janeczek et al., 2008; Shimming \& Pinto e Silva, 2013) and are described in Tables I to III and illustrated in Figures 1 to 5.

All measurements were performed with a manual calliper Starrett ${ }^{\circledR} 125$ MEB in total three times, on three different occasions by the same researcher in order to minimize the risk of measurement errors. The data were organized in spreadsheets and statistical analysis was performed (mean and standard deviation) using the software BioEstat 5.3®. The classification of the skull type of $C$. thous followed the definition of Evans \& De Lahunta for domestic dogs. 


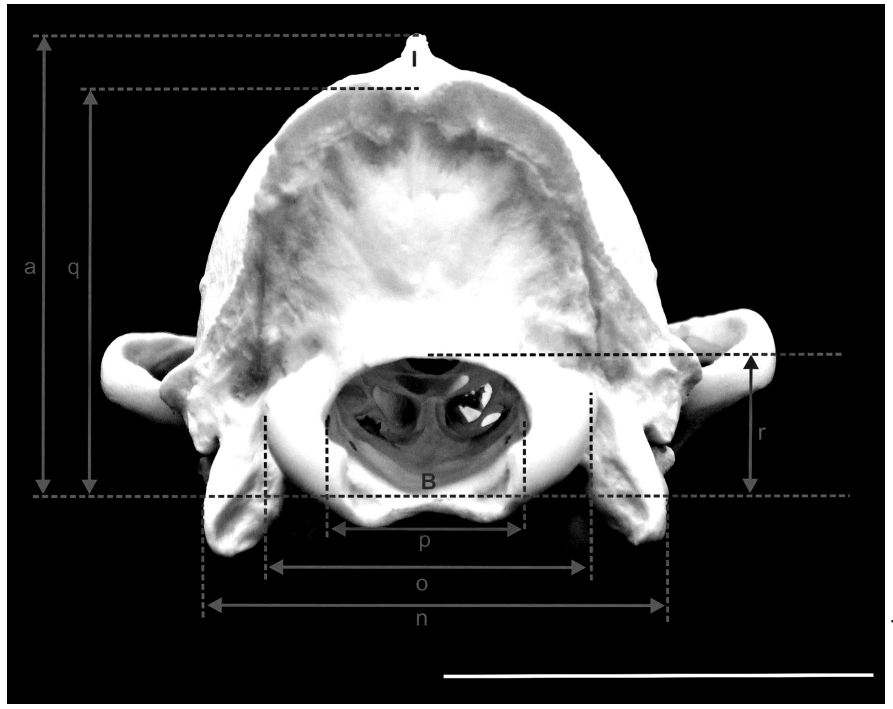

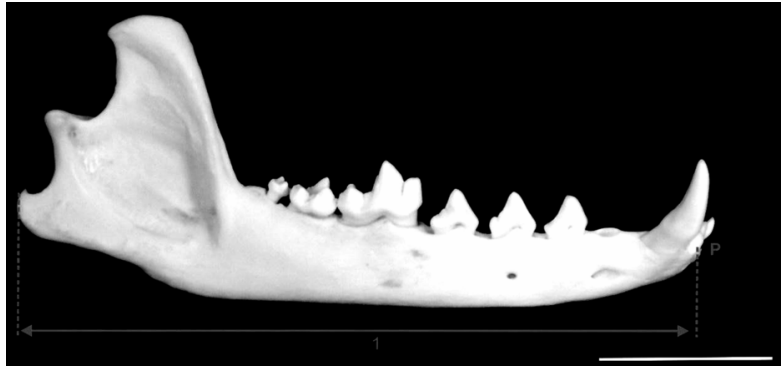

Fig. 5. Photograph of the mandible of C. thous, lateral view. P (Pogonion) and 1 (Length of the mandible). Scale: $3 \mathrm{~cm}$.

Fig. 4. Photograph of the skull of C. thous, caudal view. B (Basion), I (Inion), a (Height of the skull), $\mathrm{n}$ (Width between jugular processes), $\mathrm{o}$ (Width between occipital condyles), $\mathrm{p}$ (Width of the foramen magnum), $q$ (Height of the occipital triangle) and $\mathrm{r}$ (Height of the foramen magnum). Scale: $3 \mathrm{~cm}$.

Table I. Description of nine craniometric points.

\begin{tabular}{|c|c|c|}
\hline Name & Abbreviation & Description \\
\hline Basion & $\mathrm{B}$ & Middle of the ventral margin of the foramen magnum. \\
\hline Bregma & BR & Junction on the median plane of the right and left frontoparietal sutures. \\
\hline Eurion & $\mathrm{E}$ & Most lateral point of the neurocranium. \\
\hline Inion & I & Central surface point on the external occipital protuberance. \\
\hline Nasion & $\mathrm{N}$ & Junction on the median plane of the right and left nasofrontal sutures. \\
\hline Pogonion & $\mathrm{P}$ & $\begin{array}{l}\text { Most rostral part of the mandible, at the intermandibular articulation, located between } \\
\text { the roots of the inferior central incisor teeth. }\end{array}$ \\
\hline Prosthion & PR & $\begin{array}{l}\text { Rostral end of the interincisive suture, located betwe en the roots of the superior central } \\
\text { incisor teeth. }\end{array}$ \\
\hline Rhinion & $\mathrm{R}$ & Midline point at the inferior free end of the internasal suture. \\
\hline Zygion & $\mathrm{Z}$ & Point of maximum lateral extent of the lateral surface of the zygomatic arch. \\
\hline
\end{tabular}

Table II. Description of 12 craniometric parameters: linear measurements between craniometric points of the skull (from 'a' to 'm') and of the occipital area (from ' $n$ ' to ' $r$ ').

\begin{tabular}{|c|c|c|}
\hline Parameter & Abbreviation & Description \\
\hline Cranial height & $\mathrm{a}$ & Middle of external acoustic meatus to Bregma. \\
\hline Length of the skull & $\mathrm{b}$ & Inion to Prosthion. \\
\hline Length of the neurocranium & $\mathrm{c}$ & Inion to Nasion. \\
\hline Length of the viscerocranium & $\mathrm{d}$ & Nasion to Prosthion. \\
\hline Width of the neurocranium & e & Width of the neurocranium: distance between left and right Eurion. \\
\hline Zygomatic width & $\mathrm{f}$ & Width between left and right Zygion. \\
\hline Length of the base of the skull & $\mathrm{g}$ & Distance from Basion to Prosthion. \\
\hline Condylobasal length & $\mathrm{h}$ & Distance from Prosthion to the caudal margins of the occipital condyles. \\
\hline Length of the nose & $\mathrm{i}$ & Distance from the middle point of the oral marg in of the orbit to Prosthion. \\
\hline Length of the nasal bones & $\mathrm{i}$ & Distance from Nasion to Rhinion. \\
\hline Length of the mandible & 1 & Distance from the caudal extremity of the angular process to the Pogonion. \\
\hline Palatal length & $\mathrm{m}$ & Distance from caudal nasal spine of the palatine to the Prosthion. \\
\hline $\begin{array}{l}\text { Width between the jugular } \\
\text { processes }\end{array}$ & $\mathrm{n}$ & Width between the lateral margins of the jugular processes. \\
\hline $\begin{array}{l}\text { Width between the occipital } \\
\text { condvles }\end{array}$ & o & Width between the lateral margins of the occipital condyles. \\
\hline Width of the foramen magnum & $\mathrm{p}$ & Width between the margins of the foramen magnum. \\
\hline Height of the occipital triangle & $\mathrm{q}$ & Maximum height of the occipital triangle. \\
\hline Heig th of the foramen magnum & $\mathrm{r}$ & Distance from ventral to dorsal margin of the foramen magnum. \\
\hline
\end{tabular}


Table III. Description of six craniometric indices: ratios between craniometric parameters.

\begin{tabular}{ll}
\hline \multicolumn{1}{c}{ Indices } & \multicolumn{1}{c}{ Formula } \\
\hline Basal & Width of the neuroc ranium $\times 100 /$ length of the base of the skull. \\
Skull & Zygomatic width $\times 100 /$ length of the skull. \\
Craniofacial & Length of the skull / length of the viscerocranium. \\
Foramen magnum & Height of the foramen magnum $\times 100 /$ maximum width of the foramen magnum. \\
Neurocranial & Width of the neuroc ranium $\times 100 /$ length of the neurocranium. \\
Facial & Zygomatic width $\times 100 /$ length of the viscerocranium. \\
\hline
\end{tabular}

\section{RESULTS AND DISCUSSION}

Tables IV and V show the results (mean \pm standard deviation) of parameters measured in 11 skulls.

The length of the skull of $C$. thous in this study was 131,66 $\pm 14,86$ $\mathrm{mm}$, while Santos et al. present a skull length of $126.76 \pm 5.29 \mathrm{~mm}$ in their analysis of skulls of seven C. brachyurus, maned wolves, although $C$. thous is a considerably smaller canid (Cheida et al.). In an analysis of 25 skulls of domestic mesaticephalic dogs of unknown breed, Shimming \& Pinto e Silva (2013) mention a skull length of $177.72 \pm 16.22 \mathrm{~mm}$. Machado found a skull length of $135.19 \pm 38.61 \mathrm{~mm}$ in eight mesaticephalic dogs of different breeds and $154.56 \pm 21.22 \mathrm{~mm}$ in eight brachycephalic boxers.

The specimens of this study presented values similar to what Machado found in mesaticephalic domestic dogs. Dogs with the mesaticephalic skull type generally present a scissors bite occlusion, meaning that the maxillary incisors are located slightly rostral to the inferior incisors, allowing the dog a powerfull bite to tear its prey apart and for defence (Evans \& De Lahunta). According to Dyce et al. (1997) brachycephalic breeds present a predisposition for a shorter upper jaw, maxilla, and dolichocephalic breeds have a higher incidence of a longer than normal upper jaw (both cases resulting in problems when catching prey).

Table IV. Craniometric measurements of C. thous, in millimetres (mm).

\begin{tabular}{lccc}
\hline \multicolumn{1}{c}{ Parameter } & Abbreviation & Mean & $\begin{array}{c}\text { Standard } \\
\text { deviation }\end{array}$ \\
\hline Cranial height & $\mathrm{a}$ & 30.55 & 2.71 \\
Length of the skull & $\mathrm{b}$ & 131.66 & 14.86 \\
Length of the neurocranium & $\mathrm{c}$ & 78.84 & 8.93 \\
Length of the viscerocranium & $\mathrm{d}$ & 56.99 & 7.12 \\
Width of the neurocranium & $\mathrm{e}$ & 46.59 & 3.63 \\
Zygomatic width & $\mathrm{f}$ & 71.1 & 7.36 \\
Length of the base of the skull & $\mathrm{g}$ & 121.05 & 14.07 \\
Condylobasal length & $\mathrm{h}$ & 127.82 & 15.08 \\
Length of the nose & $\mathrm{i}$ & 52.08 & 8.13 \\
Length of the nasal bones & $\mathrm{j}$ & 39.97 & 5.24 \\
Length of the mandible & $\mathrm{l}$ & 101.66 & 14.33 \\
Palatal length & $\mathrm{m}$ & 64.02 & 7.56 \\
Width between the jugular proc esses & $\mathrm{n}$ & 34.95 & 3.13 \\
Width between the occipital condyles & $\mathrm{o}$ & 26.03 & 1.86 \\
Width of the foramen magnum & $\mathrm{p}$ & 13.73 & 0.55 \\
Height of the occipital triangle & $\mathrm{q}$ & 27.77 & 2.36 \\
Height of the foramen magnum & $\mathrm{r}$ & 8.36 & 0.52 \\
\hline
\end{tabular}

In $C$. thous the zygomatic width was $71.10 \pm 7.36 \mathrm{~mm}$, whereas Santos et al. observed $121.87 \pm 6.30 \mathrm{~mm}$ in $\mathrm{C}$. brachyurus. In mesaticephalic dogs Shimming \& Pinto e Silva (2013) report $95.44 \pm 7.85 \mathrm{~mm}$ and Machado measured $106.89 \pm 28.11 \mathrm{~mm}$ zygomatic width. In contrast, in brachycephalic dogs $139.68 \pm$ $9.63 \mathrm{~mm}$ were observed (Machado).

According to Evans \& De Lahunta the skull index is $39 \mathrm{~mm}$ in dolichocephalic dogs, $52 \mathrm{~mm}$ in mesaticephalic and $81 \mathrm{~mm}$ in brachycephalic dogs. The skull index for C. thous, observed in this study, was 53.17 $\pm 2.54 \mathrm{~mm}$, resembling the skull index of mesaticephalic dogs as described by Evans \& De Lahunta. Similar values were also observed in the German Shepherd breed by Onar (1999) and in domestic dogs of unknown breed by Shimming \& Pinto e Silva \%, describing a skull index of 51.44 $\mathrm{mm}$ and $53.83 \pm 3.36 \mathrm{~mm}$, respectively.

On the other hand, Santos et al. present a skull index of $96.17 \pm 3.89 \mathrm{~mm}$ for C. brachyurus. This raises some questions, since C. brachyurus and C. thous belong to the same subtribe Cerdocyonina. However, probably the discrepancy

Table V. Craniometric indices in C. thous, in millimetres (mm).

\begin{tabular}{lcc}
\hline \multicolumn{1}{c}{ Indices } & Mean & $\begin{array}{c}\text { Standard } \\
\text { deviation }\end{array}$ \\
\hline Basal & 37,52 & 2,65 \\
Skull & 53,17 & 2,54 \\
Craniofacial & 2,33 & 0,08 \\
Facial & 125,58 & 6,63 \\
Foramen magnum & 54,47 & 3,48 \\
Neurocranial & 59,17 & 3,57 \\
\hline
\end{tabular}


between the indices of the two species is a result of methodological errors in the work of Santos et al., as their calculations might be based on wrong measurements, as they report a cranial length for the maned wolf inferior to what is described in this study for $C$. thous, even though $C$. thous is the smaller species. The results of this study were not compared with the work of Machado, since the cited work employs only the craniofacial index for defining the type of skull.

\section{CONCLUSION}

The craniometric points described in the crab-eating fox, were similar to what is established for the domestic dog and therefore the craniometric indices were calculated in the same way as is common for the domestic dog. This study shows that the craniometric characteristics of $C$. thous follows what is described for the domestic dog and its skull type can be classified as mesaticephalic.

\section{ACKNOWLEDGMENTS}

This study was financed in part by the Coordenação de Aperfeiçoamento de Pessoal de Nível Superior - Brasil (CAPES) - Finance Code 001.

\section{NETO, ANTONIO M.; VIOTTO DE SOUZA, W.; FROMME, L.; DOMINGUES, M. G.; GUIMARÃES, L. P.; SILVA, T. A. \& SANTOS, A. L. Q. Craneometría en Cerdocyon thous (Carnivora, Canidae). Int. J. Morphol., 38 (3):640-644, 2020.}

RESUMEN: El objetivo de este estudio fue obtener datos sobre los parámetros craneométricos del zorro cangrejero (Cerdocyon thous) y definir el tipo general de cráneo de esta especie, analizando si se puede aplicar la clasificación craneométrica de los perros domésticos. Once cráneos de $C$. thous fueron incluidos en el análisis, independientemente de la edad y el sexo. Se determinó la ubicación de nueve puntos craneométricos establecidos para la craneometría en perros domésticos y, en función de las distancias entre estos puntos, se midieron 17 parámetros craneométricos. Esos parámetros se usaron para calcular los siguientes índices craneométricos: índice craneal de 53,17 $\pm 2,54$ $\mathrm{mm}$, índice craneofacial de 2,33 $\pm 0,08 \mathrm{~mm}$, índice neurocraneal de 59,17 $\pm 3,57 \mathrm{~mm}$, índice facial de 125,58 $\pm 6,63 \mathrm{~mm}$, índice basal de 37,52 $\pm 2,65 \mathrm{~mm}$ y el índice del foramen magnum $54,47 \pm$ $3,48 \mathrm{~mm}$. Según los índices analizados, la forma del cráneo en $C$. thous se puede clasificar como mesaticefálica.

PALABRAS CLAVE: Cánido silvestre; Cráneo; Morfometría.

\section{REFERENCES}

Berta, A. Cerdocyon thous. Mamm. Species, (186):1-4, 1982.

Cheida, C. C.; Nakano-Oliveira, E.; Fusko-Costa, R.; Rocha-Mendes, F. \& Quadros, J. Ordem Carnívora. In: Reis, N. R.; Peracchi, A. L.; Pedro, W. A. \& Lima, I. (Eds.). Mamíferos do Brasil. Londrina, Nelio R. dos Reis, 2011. pp.235-88.

Christiansen, P. \& Adolfssen, J. S. Bite forces, canine strength and skull allometry in carnivores (Mammalia, Carnivora). J. Zool., 266(2):133-51, 2006.

Christiansen, P. Scaling of mammalian long bones: small and large mammals compared. J. Zool., 247(3):333-48, 1999.

Dyce, K. M.; Sack, W. O. \& Wensing, C. J. G. Tratado de Anatomia Veterinária. $2^{\text {nd }}$ ed. Rio de Janeiro, Guanabara Koogan, 1997.

Emmons, L. H. \& Feer, F. Neotropical rainforest mammals: a field guide. $2^{\text {nd }}$ ed. Chicago, University of Chicago Press, 1997.

Evans, H. E. \& De Lahunta, A. Miller's Anatomy of the Dog. $4^{\text {th }}$ ed. Philadelphia, Saunders Elsevier, 2013.

Ferguson, S. H. \& Larivière, S. Are long penis bones an adaption to high latitude snowy environments? Oikos, 105(2):255-67, 2004.

Getty, R. Anatomia dos Animais Domésticos. 5th ed. Rio de Janeiro, Guanabara Koogan, 1986.

Goswami, A. Morphological integration in the carnivoran skull. Evolution, 60(1):169$83,2006$.

Hofmann-Appollo, F. Estudo Comparativo da Forma do Crânio de Cães Braquicefálicos e Mesaticefálicos por meio de Técnicas de Morfometria Geométrica em Três Dimensões. M.Sc. Dissertation. São Paulo, University of São Paulo, 2009.

Janeczek, M.; Chrószcz, A.; Onar, V.; Pazvant, G. \& Pospieszny, N. Morphological analysis of the foramen magnum of dogs from the Iron Age. Anat. Histol. Embryol., 37(5):359-61, 2008

Langguth, A. Ecology and Evolution in the South American Canids. In: Fox, M. W. (Ed.). The Wild Canids: Their Systematics, Behavioral Ecology and Evolution. Washington, Dogwise Publishing, 1975. pp.192-206.

Lucherini, M. Cerdocyon thous. The IUCN Red List 2015. 2015. Available from: http:// dx.doi.org/10.2305/IUCN.UK.2015-4.RLTS.T4248A81266293.en.

Lyras, G. A. \& Van Der Geer, A. A. E. External brain anatomy in relation to the phylogeny of Caninae (Carnivora: Canidae). Zool. J. Linn. Soc., 138(4):505-22, 2003.

Machado, F. de A. \& Hingst-Zaher, E. Investigating South American biogeographic history using patterns of skull shape variation on Cerdocyon thous (Mammalia: Canidae). Biol. J. Linn. Soc., 98(1):77-84, 2009.

Machado, T. F. S. Estudo Comparativo da Localização do Seio Venoso Sagital Dorsal no Crânio de Cães Braquicefálicos e Mesaticefálicos para Craniotomia Transfrontal. M.Sc. Dissertation. São Paulo, University of São Paulo, 2006.

Moura, C. E. B.; Albuquerque, J. F. G.; Magalhães, M. S.; Silva, N. B.; Oliveira, M. F. \& Papa, P. C. Análise comparativa da origem do plexo branquial de catetos (Tayassu tajacu). Pesq. Vet. Bras., 27(9):357-62, 2007.

Nickel, R.; Schummer, A.; Seiferle, E.; Wilkens, H.; Wille, K-H. \& Frewein, J. The Anatomy of the Domestic Animals. The Locomotor System of the Domestic Mammals. Berlin, Paul Parey, 1986

Onar, V. \& Günes , H. On the variability of skull shape in German shepherd (Alsatian) puppies. Anat. Rec. A Discov. Mol. Cell. Evol. Biol., 272(1):460-6, 2003.

Onar, V. A morphometric study on the skull of the German shepherd dog (Alsatian). Anat. Histol. Embryol., 28(4):253-6, 1999.

Santos, A. L. Q.; Paz, B. F.; Barros, R. F.; Nalla, S. R. \& Pereira, T. S. Craniometria em lobos-guará Chrysocyon brachyurus Illiger, 1815 (Carnivora, Canidae). Cienc. Anim. Bras., 18:e37693, 2017.

Sarma, M.; Kalita, A.; Baishya, G. \& Goswami, R. N. Craniometry in domestic cat. Indian Vet. J., 79(12):1262-5, 2002.

Shimming, B. C. \& Pinto e Silva, J. R. C. Craniometria em cães (Canis familiaris) Aspectos em crânios mesaticéfalos. Braz. J. Vet. Res. Anim. Sci., 50(1):5, 2013.

Simoens, P.; Poels, P. \& Lauwers, H. Morphometric analysis of the foramen magnum in Pekingese dogs.. Am. J. Vet. Res., 55(1):34-9, 1994.

Corresponding author:

Master student Wilson Viotto de Souza

Laboratory of Wild Animals Teaching and Research to UFU

Street Piaui, street corner Professor José Inácio de Souza,

Block 4S

CEP 38405-317

Uberlândia, MG - BRAZIL

Received: 27-09-2019

Email: wilson.viotto@gmail.com

Accepted: 26-11-2019 